\title{
BRUYEVA V.
}

Ukrainian Engineering and Pedagogical Academy, Kharkiv, Ukraine

\section{QUALIMETRIC TOOLS OF ADAPTIVE TECHNOLOGY FOR TRAINING MASTERS OF INTELLECTUAL PROPERTY MANAGEMENT}

The article is devoted to the expediency of developing, implementing qualimetric tools and qualimetric models in the training of masters of intellectual property management. The analysis of scientific sources that update the involvement of qualimetric tools in the preparation of undergraduates as an integral part of adaptive technology is made. The definitions essence of qualimetric tools, qualimetric models, adaptive technology, context-concentric approach in the training of masters of intellectual property management is revealed.

The importance of simultaneous involvement of systematic management and pedagogical activities in the preparation of masters (through the introduction of a context-concentric approach, adaptive technology and qualimetric modeling) is emphesised. The own qualimetric algorithm for measuring and evaluating the professional training quality of masters of intellectual property management is proposed, which is based on a coordinated partnership of the triad "teacher-master-employer" and aimed at forming integrated competencies in undergraduates. It is proposed to develop and use qualimetric models in the preparation of masters of intellectual property management in three modes of simulation (for a certain past period of time, for the present, for a certain period of time with the predicted measurement). It is offered to combine qualimetric modeling masters of management of intellectual property preparation in three notations: functions; data streams; flows of specific activities. The list of integrated competencies for masters of intellectual property management, which should be formed during the complex functioning of adaptive technology, context-concentric approach and involvement of qualimetric modeling is singled out and presented. The list of requirements to teachers, management of educational institution concerning effective creation and use of qualimetric tools in the preparation course of masters is given.

Key words: adaptive technology, qualimetric tools, qualimetric modeling, algorithm, master's degree training, integrated competencies, intellectual property market

Стаття надійшла до редакції 01.08.2020 p.

УДК 378.016:91-028.22

DOI: https://doi.org/10.33989/2075-146x.2020.25.223184

ЛЮБОВ ВІШНІКІНА

ORCID: 0000-0003-0976-5512

ТЕТЯНА ЯПРИНЕЦЬ

ORCID: 0000-0002-5844-3520

АНЖЕЛА ШУКАНОВА

ORCID: 0000-0002-9520-713X

Полтавський національний педагогічний університет імені В. Г. Короленка СУЧАСНИЙ ПІДХІД ДО ЗАСТОСУВАННЯ НАВЧАЛЬНОГО ГРАФІЧНОГО
МОДЕЛЮВАННЯ У ПРОЦЕСІ НАВЧАННЯ ГЕОГРАФІЧНИХ ДИСЦИПЛІН

\begin{abstract}
Окреслено особливості навчального графічного моделювання як педагогічної технології та визначено можливості їі застосування у процесі підготовки майбутніх вчителів географії; схарактеризовано навчальні графічні моделі, методичні умови їхнього створення й застосування; висвітлено процесуальні складники скрайбінгу як методичного прийому.
\end{abstract}

Ключові слова: навчальне графічне моделювання, педагогічна технологія, навчальна модель, майбутні вчителі географії, скрайбінг

Постановка проблеми та іï зв'язок із важливими науковими та практичними завданнями. Глобалізація та елементи постіндустріальної трансформації впливають на різні структури нашого суспільства і висувають перед ним нові задачі, вирішення яких неможливе за умови відсутності сучасного географічного мислення у представників усіх верств населення. Відповідно до такого, підвищення ефективності географічної освіти зумовлене сучасними суспільними викликами. Не менш важливо це для розвитку географії як науки, оскільки сучасні розвідки у її царині потребують залучення представників нових поколінь, відкритих до нестандартних підходів на підгрунті застосування технологічних інновацій.

Нині дидактика географії проходить складний період модернізації. У нових освітніх стандартах, окрім змістового компонента спеціальностей, описано не лише загальні й фахові компетентності, а й конкретні навчальні результати. Відповідальність за досягнення вказаних результатів студентами значною мірою покладається на викладачів закладів вищої освіти (ЗВО). За таких умов гостро постає питання вдосконалення їхньої педагогічної майстерності, здатності творчо підходити до організації освітнього процесу, перебудовувати його на засадах компетентнісного, студентоцентрованого та конструктивно-проблемного підходів до навчання. Наразі важливим 
підгрунтям творчої діяльності $\epsilon$ викладачів $\epsilon$ їхня обізнаність щодо сучасних педагогічних технологій, які використовують новітні засоби зберігання й передавання інформації, організації комунікації суб'єктів освітнього процесу тощо. Варто зазначити, що поняття «педагогічна технологія» трансформувалось від початкового уявлення про неї як «навчання за допомогою технічних засобів», до розуміння ії як «системного і послідовного втілення в практику будь-якого рангу заздалегідь спроектованого навчально-виховного процесу» (Вішнікіна, 2017, с. 278).

Однією із таких технологій $є$ технологія застосування навчального графічного моделювання. Основним алгоритмом, покладеним в іiі основу, є візуалізація навчального матеріалу, яка здійснюється під час моделювання географічних об'єктів, процесів і явищ. Результатом моделювання стає створення навчальних графічних моделей (НГМ) різних видів, що забезпечують можливість аналізувати географічні об'єкти вивчення, які 3 об'єктивних причин неможливо представити студентам чи учням у натуральному виді.

Ця технологія ще у 90-ті роки минулого століття набула поширення у шкільній географічній освіті, проте у 3ВО застосовувалася фрагментарно. Звісно, відсутність відповідних технічних засобів дещо обмежувала дидактичні можливості застосування навчального графічного моделювання, що знижувало ефективність його використання.

Нині у вітчизняному освітньому просторі поширилося впровадження сучасних технологій, методик і прийомів навчання, які були запозичені за кордоном - лепбукинг (LAPBOOKING), скрайбінг (SCRIBING), iнсерт (INSERT), рафт (RAFT), слант (SLANT), Web-квест та інші. Усі вони почали активно входити до методичного арсеналу викладачів і вчителів географії, що безперечно є прогресивним процесом. На нашу думку скрайбінг за дидактичною метою і алгоритмом здійснення є доволі близьким до технології навчального графічного моделювання. Наразі доречно переглянути теоретичні і практичні засади цієї технології, доповнити ії технологічними інноваціями скрайбінгу з метою подальшої розробки і впровадження у процес навчання географії як у вищій, так і в старшій та основній школі. Саме цій доволі актуальній проблемі було присвячене наше дослідження.

Аналіз найвагоміших публікацій, у яких започатковано розв'язання досліджуваної проблеми. Проблема ефективного застосування навчального графічного моделювання у процесі навчання географії аналізувалася у роботах багатьох науковців, методистів і педагогів-практиків. Питанням класифікації географічних НГМ були присвячені публікації А. Андріянова, П. Барабохи, Л. Вішнікіної, Н. Гаврилик-Титар, Г. Камерілової, Л. Костенко, Н. Люхіної, С. Мовчана, В. Самойленка, О. Солонька, О. Топузова та інших. У працях Л. Вішнікіної, М. Винокур, Г. Камерілової, С. Коберніка, Л. Костенко, Н. Муніч, С. Пальчевського, Л. Підоріної О. Скуратовича, О. Солонька, О. Топузова, В. Шаталова, Н. Шулдик та інших характеризуються умови, за яких робота учнів з НГМ стає засобом підвищення їхньої активності, або розглядаються конкретні дії, які виконуються з моделями під час навчального графічного моделювання.

Втім, недостатньо дослідженою залишається проблема застосування навчального графічного моделювання у процесі формування фахових компетентностей майбутніх учителів географії. На сучасному етапі розвитку шкільної географічної освіти відбувається зміна поколінь педагогів, до школи приходять молоді фахівці із розвиненими навичками використання сучасних мультимедійних (а поміж них і гаджетних) засобів. Тому формування вміння майбутніх вчителів географії застосовувати модернізоване навчальне графічне моделювання, поєднуючи його із використанням сучасних технічних засобів, $є$ нагальною потребою сьогодення.

Методологічні засади нашого дослідження грунтувався на роботах чисельної групи дослідників, яких ми називали вище. Схарактеризуємо внесок деяких із них. О. Летягін обгрунтував зміст поняття «навчальна модель» $\mathrm{i}$ окреслив дидактичні умови ії застосування. Він зазначав, що» навчальна модель являє собою тримірний (інколи двомірний) навчально-наочний засіб, що зображує якийсь об'єкт з певним ступенем спрощення задля виділення головних ознак, що вивчаються» (Душина, Пятунин, \& Летягин, 2007, с. 154).

Значний внесок у визначення психолого-педагогічних засад навчального моделювання належить Н. Салміній, яка характеризує навчальну модель «як одну із форм знаково-символічної предметності, що презентує матеріалізовані знання» (Салміна, 1988, с 9).

Особливості безпосередньо географічного навчального графічного моделювання схарактеризовано у працях В. Самойленка. Зокрема, моделювання у геоекології він кваліфікує як «дослідження структури, функціонування, динаміки, стійкості, стану та розвитку реальних геосистем, зв'язків та процесів усередині них, між ними та із зовнішнім середовищем за допомогою моделей» (Самойленко, 2003, с. 6).

Один із засновників вітчизняної дидактики географії Є. Шипович зазначає, що при здійсненні малювання $\mathrm{i}$ креслення на дошці (графічного моделювання) «мобілізується зорова, слухова і моторна пам'ять та посилюється увага учнів до пояснюваного учителем матеріалу. Крім того, учні роблять малюнки у своїх зошитах, набувають певних навичок і умінь, використовують ці малюнки при відповідях. ... Учні краще запам'ятовують, осмислюють явище, зв'язки, закономірності» (Шипович, 1981, с. 111).

Незважаючи на великий обсяг публікацій, присвячених проблемі нашого дослідження, не з'ясованим залишаються питання модернізації технології застосування навчального графічного моделювання, застосування викладачами 3ВО нових засобів, технік і прийомів навчання географії, які наразі ввійшли у шкільну практику.

Метою статті є визначення сучасного стану впровадження технології навчального графічного моделювання у процес навчання географії та окреслення напрямів іï модернізації 3 метою формування професійних компетентностей майбутніх учителів географії.

Виклад основного матеріалу дослідження. Перш за все, варто зазначити, що з одного боку, НГМ тривалий час використовувалися вчителями географії у навчальному процесі. 3 іншого боку, функції таких моделей і дидактичні особливості навчального графічного моделювання вчителі розуміють неоднозначно.

3 метою детальнішого вивчення проблеми підвищення ефективності застосування технології навчального графічного моделювання ми провели анкетування 22 учителів географії з досвідом роботи від 1 до 20 років, які навчалися на курсах підвищення кваліфікації у Полтавському обласному інституті післядипломної педагогічної освіти імені М.В. Остроградського. Анкетування було спрямоване на визначення того, чи використовують учителі у 
своїй практичній діяльності навчальні моделі та як вони ставляться до проблеми застосування таких моделей на уроках географії. Крім того, для конкретизації відповідей учителів на запитання анкети і подальшого узагальнення та аналізу відповідей було проведено уточнюючі бесіди.

Запропонована вчителям анкета вміщувала шість питань:

1. Чи використовуєте Ви на уроках навчальні моделі?

2. Які навчальні моделі Ви найчастіше використовуєте на уроках?

3. 3 якою дидактичною метою Ви використовуєте навчальні моделі?

4. Які властивості навчальних моделей $є$ визначальними при навчанні географії?

5. Які навчальні прийоми Ви застосовуєте під час роботи з навчальними моделями?

6. Які форми організації навчальної діяльності учнів є найбільш ефективними під час їхньої роботи 3 навчальними моделями?

Аналіз відповідей учителів, одержаних внаслідок анкетування та індивідуальних бесід з ними, дозволив зробити наступні висновки:

- усі вчителі географії використовують на уроках навчальні моделі, але у більшості випадків вони використовують готові навчальні моделі;

- більшість учителів географії під поняттям «модель» розуміють об'ємне тримірне зображення географічного об'єкта;

- усі вчителі використовують на уроках географічні карти і більшість 3 них усвідомлює, що вони $є$ просторовими навчальними моделями;

- комп'ютерні моделі на уроках географії застосовують $22 \%$ учителів, що пояснюється недостатнім забезпеченням кабінетів географії комп'ютерами, а також слабко розвинутою методичною базою для їхнього застосування;

- 45\% учителів вказали, що вони систематично або фрагментарно застосовують НГМ, але вбачають в них засіб організації запам'ятовування навчального матеріалу;

- визначаючи мету використання навчальних моделей, більшість учителів називають наочність, зазначаючи, що наочність моделей концентрує увагу учнів, сприяє підвищенню швидкості розуміння навчального матеріалу, його запам’ятовуванню, дає змогу створити образ об'єкта вивчення;

- коли вчителі говорять про застосування навчальних моделей з метою організації практичної та самостійної роботи учнів, вони мають на увазі картографічні дидактичні матеріали;

- майже половина вчителів не розглядає навчальні моделі як засіб самостійного здобування знань та активізації пізнавальної діяльності учнів;

- на запитання, які навчальні прийоми вчителі використовують під час роботи з моделлю, здебільшого вчителі називають вербальні прийоми навчання (розповідь, пояснення, бесіда). Поміж ілюстративно-демонстраційних прийомів найчастіше вживаним є ілюстрування. Втім, ілюструються переважно зовнішні ознаки об'єкта вивчення;

- виконання вправ та інших практичних дій з навчальними моделями вчителі переважно пов'язують із використанням карт і глобусів;

- найуживанішою формою організації навчання учнів є фронтальна, і лише $35 \%$ вчителів назвала індивідуальну форму організації навчання як можливу при роботі з навчальними моделями..

Аналіз і узагальнення результатів анкетування та бесід з учителями географії дає змогу зробити висновок, що вони часто застосовують навчальні моделі у своїй практиці. Проте, найчастіше вчителі розуміють під навчальними моделями об'ємні зображення географічних об'єктів, а моделювання визначають як побудову таких моделей. Це свідчить про переважання предметного підходу до моделювання, який є доволі обмеженим у дидактичному сенсі. Можливо цей факт пояснюється тим, що у педагогічній літературі поняття «модель» і «моделювання» застосовуються неоднозначно. Тож учителі не мають чіткого розуміння щодо місця і функцій моделей у навчанні. Використовуючи навчальні моделі, вони часто не усвідомлюють, що метою їхнього застосування є дослідження географічних об'єктів вивчення, а не заучування навчального матеріалу. Але найбільшою проблемою, на наш погляд, $€$ той факт, що лише половина опитаних учителів пов'язують застосування навчальних моделей 3 організацією пізнавальної діяльності учнів.

Задля розуміння сутті технології застосування навчального графічного моделювання доцільно конкретизувати ііі термінологічний апарат, тобто з'ясувати значення понять «навчальна модель» і власне «навчальне моделювання». В Українському педагогічному словнику наводиться тлумачення: «Моделі (від латинської назви modulus - міра, мірило, зразок) - навчальні посібники, які є умовним образом (зображення, схема, опис тощо) якогось об'єкта (або систем об’єктів), який зберігає зовнішню схожість і пропорції частин» (Гончаренко, 1997, с. 213].

У нашому дослідженні навчальну графічну модель ми розглядали як вид знаково-символічної ідеалізації, що набув матеріальної реалізації і покликаний відтворювати об'єкт вивчення у процесі організації пізнавальної діяльності студентів чи учнів. Моделі, що використовуються на заняттях із географії належать до засобів візуалізації, які завдяки активізації когнітивних просів мають забезпечувати активну пізнавальну діяльність. Створення викладачем чи вчителем графічної навчальної моделі у співпраці зі студентами чи учнями має надавати їм можливість здобувати нові знання щодо географічного об’єкта-оригіналу.

Оскільки під час навчання географії більшість об'єктів довкілля не можуть сприйматися студентами чи учнями безпосередньо, виникає потреба у їхній заміні моделями того чи іншого функціонального спрямування. Відповідно до такого спрямування модель-замінник не може бути точною копією об'єкта-оригіналу і відбиває лише ті його властивості і зв'язки, які вивчаються на даному етапі.

Таким чином, на нашу думку, навчальна графічна модель - це відображення географічного об’єкта, процесу або явища, створене графічно-знаковими символічними засобами з метою одержання і фіксації актуальної інформації 
про них й наступним перетворенням на предмет дослідження, що спрямовано на організацію пізнавальної діяльності студентів чи учнів.

Для того, щоб навчити майбутніх учителів географії ефективно застосовувати НГМ, необхідно навчити їх усвідомлювати механізм дії структурно-логічної графіки. Вони мають розуміти специфічні особливості НГМ, а саме:

- графічна навчальна модель є знаковою;

- образ і знак у моделі не тільки не вилучають одне одного, а навпаки - взаємодоповнюються;

- модель і має оперативну функцію, оскільки вказує на спосіб організації діяльності, спрямованої на виявлення суттєвих властивостей об'єкта вивчення;

- евристична функція моделі полягає у спрямуванні студента чи учня на розв'язання проблемних запитань $\mathrm{i}$ завдань.

У процесі графічного навчального моделювання, яке передбачає можливість згортання значного обсягу навчальної інформації та іiі візуалізацію, відбувається створення НГМ. При цьому географічний навчальний матеріал стискується, структурується і систематизується за активної участі студентів чи учнів. НГМ можуть створюватися за допомогою мультимедійних засобів, а за їхньої відсутності модель відтворюється на традиційній класній дошці.

Прикладом навчальної графічної моделі, яка може бути змодельована студентами-географами і використана на практичному занятті з дисципліни «Географія Полтавської області» є модель, представлена на малюнку 1. Графічна навчальна модель «Природа Полтавщини», що вміщує великий обсяг навчальної інформації, будується студентами у співпраці із викладачем упродовж кількох практичних занять. При цьому у майбутніх учителів формуються не тільки здатність здобувати географічні знання, що потрібні для побудови моделі, а й вміння моделювати $\mathrm{i}$ візуалізувати географічну навчальну інформацію.

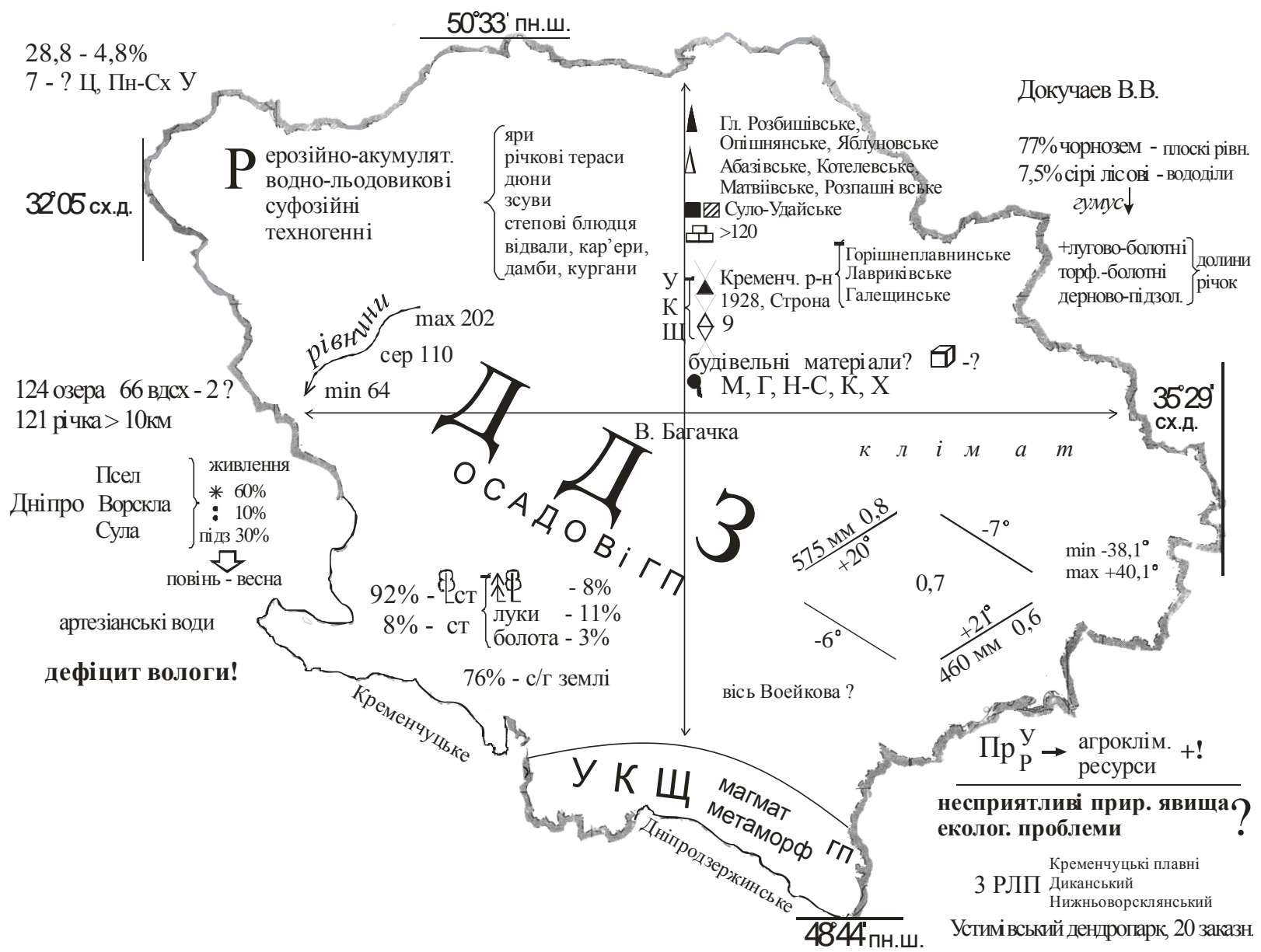

Рис. 1 Природа Полтавщини

Втім, створення НГМ не $є$ кінцевою метою навчального графічного моделювання. У процесі такого моделювання модель слугує засобом логічного упорядкування навчального матеріалу. Пріоритетною основою навчального моделювання $є$ формування предметних географічних компетентностей студентів, прийомів їхньої пізнавальної діяльності та розвиток критичного мислення. Крім того, студенти, застосовуючи моделювання як пізнавальний метод, усвідомлюють його психодидактичні особливості, що дозволить їм у майбутньому організовувати пізнавальну діяльності учнів. 
Варто нагадати, що у Законі України «Про вищу освіту» поміж провідних завдань ЗВО однією із основних вимог $\epsilon$ «забезпечення органічного поєднання в освітньому процесі освітньої, наукової та інноваційної діяльності» (Про вищу освіту, 2014, с. 6).

Відповідно до такого, варто розглянути проблему модернізації технології застосування навчального графічного моделювання. Якщо звернутися до закордонних інновацій, які ми називали вище, то найбільш близькою, у даному сенсі, є технологія скрайбінгу. Відповідно до такого, варто розглянути проблему модернізації технології застосування навчального графічного моделювання. Якщо звернутися до закордонних інновацій, які ми називали вище, то найбільш близькою, у даному сенсі, є технологія скрайбінгу.

Скрайбинг у перекладі з англійської мови означає описувати, робити нотатки, окреслювати тощо. Вперше він був застосований як інтерактивний засіб візуалізації навчальної інформації американським викладачем Полом Богушем, який започаткував створення й використання скрайб-презентацій (Освіта.UA. II Всеукраїнський скрайбінг-фест, 2020).

Аналіз чисельних Інтернет джерел показав неоднозначність розуміння цього терміну. Скрайбинг розглядають як метод або прийом навчання, педагогічну техніку або технологію, спосіб візуалізації або вид презентації. Скрайбінг поєднує розповідь чи пояснення із графічним ілюструванням головної сутті навчального матеріалу. Тобто здійснюється синхронна візуалізація аудіального ряду, яка спрямована на формування уявлень, понять, причиннонаслідкових зв'язків тощо. Особливістю скрайбінгу є переважання образної графіки, лаконічність і спрощеність візуальних засобів.

Наразі виділилося такі види скрайбінгу:

- скрайбінг-фасиліфікація - візуалізація навчальної інформації у реальному часі;

- відеоскрайбінг - створення відеороликів, які можна використовувати 3 метою візуалізації навчальної інформації багаторазово;

- онлайн-скрайбінг - використання спеціальних комп'ютерних програм й онлайн-сервісів, за допомогою яких створюють відеопродукти відповідного призначення (Освіта.UA. II Всеукраїнський скрайбінг-фест, 2020).

Якщо проаналізувати описані особливості скрайбінгу у відповідності з дидактичними категоріями, доцільно ідентифікувати його як методичний прийом навчання. Як зазначалося у наших попередніх роботах «методичні прийоми навчання грунтуються на різноманітному поєднанні навчальних засобів, форм організації навчальнопізнавальної діяльності і способів різних логічних шляхів викладання навчального матеріалу» (Вішнікіна, 2017, c. 88$)$.

Отже, скрайбінг має ознаки вербального й ілюстративно-демонстраційного методичних прийомів. Недоліками цього методичного прийому є його спрямування на заучування сенсу нової інформації. Тож доцільно його вдосконалювати відповідно до сучасних освітніх вимог - активізації самостійної пізнавальної діяльності студентів $\mathrm{i}$ учнів.

Висновки з дослідження i перспективи подальших розвідок у даному напрямку. На нашу думку, привнесення технологічних особливостей скрайбінгу до технології навчального графічного моделювання сприятиме iї модернізації. У такому оновленому виді застосування цієї технології у процесі підготовки майбутніх учителів географії буде сприяти більш ефективному формуванню їхніх фахових компетентностей і досягненню запланованих навчальних результатів.

Майбутні розвідки, спрямовані на розв'язання поставленої у нашому дослідженні проблеми, пов'язані із прикладними аспектами модернізації навчального графічного моделювання: розробкою ГНМ відповідно до змісту географічних навчальних дисциплін, спрощення графічної символіки та збільшення частки асоціативно-образних зображень у ГНМ, застосування доступних для використання програмних засобів. Лише творчий підхід, креативна мислення та пошук нових шляхів у педагогічній діяльності дозволить зробити процес навчання географії цікавим, ефективним і привабливим для нового покоління студентів та їхніх майбутніх учнів.

\section{Список використаних джерел}

Вішнікіна, Л. П. (2017). Компетентнісне навчання географї в основній школі. Полтава: АСМІ.

Гончаренко, С. У. (1997). Український педагогічний словник. Київ: Либідь.

Душина И. В., Пятунин В. Б., \& Летягин А. А. (2007). Методика обучения географии в общеобразовательных учреждениях : учеб. пособ. для студентов вузов. Москва: Дрофа.

Освіта.UA. II Всеукраїнський скрайбінг-фест. Скрайбінг - новітня техніка презентації. 2020. Взято 3 https://osvita.ua/school/scribing/51803/

Про вищу освіту: Закон України від 1 лип. 2014 р. № 1556-VII. Офіиійний вісник Украӥни, 6.

Салміна, Н. Г. (1988). Знак и символ в обучении. Москва: Изд-во МГУ.

Самойленко, В. М. (2003). Математичне моделювання в геоекології. Київ: Вид.-полігр. центр «Київський університет».

Шипович, С. Й. (1981). Методика викладання географії. Київ: Вища школа. 


\section{References}

Dushina I. V., Piatunin V. B., \& Letiagin A. A. (2007). Metodika obucheniia geografii v obshcheobrazovatelnykh uchrezhdeniiakh

[Methods of teaching geography in educational institutions]: ucheb. posob. dlia studentov vuzov. Moskva: Drofa [in Russian].

Honcharenko, S. U. (1997). Ukrainskyi pedahohichnyi slovnyk [Ukrainian pedagogical dictionary]. Kyiv: Lybid [in Ukrainian].

Osvita.UA. II Vseukrainskyi skraibinh-fest [Education.UA. II All-Ukrainian scribing fest]. Skraibinh - novitnia tekhnika prezentatsii [Scribing is the latest presentation technique]. 2020. Retrieved from https://osvita.ua/school/scribing/51803/ [in Ukrainian].

Pro vyshchu osvitu [About higher education]: Zakon Ukrainy vid 1 lyp. 2014 r. № 1556-VII. Ofitsiinyi visnyk Ukrainy [Official Gazette of Ukraine], 6 [in Ukrainian].

Salmina, N. G. (1988). Znak i simvol v obuchenii [Sign and symbol in training]. Moskva: Izd-vo MGU [in Russian].

Samoilenko, V. M. (2003). Matematychne modeliuvannia v heoekolohii [Mathematical modeling in geoecology]. Kyiv: Vyd.-polihr. tsentr "Kyivskyi universytet" [in Ukrainian].

Shypovych, Ye. Y. (1981). Metodyka vykladannia heohrafii [Methods of teaching geography]. Kyiv: Vyshcha shkola [in Ukrainian].

Vishnikina, L. P. (2017). Kompetentnisne navchannia heohrafii v osnovnii shkoli [Competence teaching of geography in primary school]. Poltava: ASMI [in Ukrainian].

VISHNIKINA L., YAPRYNETS T., SHUKANOVA A.

Poltava V. G. Korolenko national pedagogical University, Ukraine

\section{MODERN APPROACH TO THE APPLICATION OF EDUCATIONAL GRAPHIC MODELING IN THE PROCESS} OF TEACHING GEOGRAPHICAL DISCIPLINES

The article analyzes the current problem of modernization of higher education teaching methods, which is associated with the problem of improving the efficiency of training of future geography teachers. Based on the review of the most important publications on the research topic, aspects of the problem that require further research are identified. The necessity of introduction of pedagogical technologies by teachers, in particular technologies of application of educational graphic modeling is proved, and its main algorithm is defined. Foreign methodological innovations that are pro-actively used in the practice of teaching geography are specified. The results of the survey of geography teachers, conducted to specify ways to improve the efficiency of the application of educational graphic modeling technology, are analyzed. It was found that educational models were used by teachers, but mainly in order to organize the memorization of the basic meaning of educational material. Not all teachers understand the didactic nature and objectives of educational modeling. Attention is paid to the definition of the conceptual and categorical apparatus; the author's definitions of the concepts "pedagogical technology", "educational graphic model", "educational reception" are formulated. The authors highlight the specific features of educational graphic models. They prove that future geography teachers will master the didactic principles of the relevant technology, only when they use educational graphic modeling while the studying geographical disciplines. The article presents the educational graphic model "Nature of Poltava region" and characterizes its purpose. For the purpose of modernization of educational graphic modeling the paper offers to use scribing which combines the basic didactic characteristics of verbal and illustrative-demonstration methodical techniques. The areas of further researches of the problem in issue are defined: development of new educational graphic models, simplification of graphic symbolics and increase of a share of their associative-vivid images, application of available software.

Key words: educational graphic modeling, pedagogical technology, educational model, future teachers of geography, scribing

Стаття надійшла до редакції 27.07.2020 p. 